\title{
Will Pharmacogenomics Take the Pain Out of Pain Medication?
}

\section{Pramod B Mahajan*}

Department of Pharmaceutical, Biomedical and Administrative Sciences, College of Pharmacy and Health Sciences, Drake University, USA

According to recent data briefs from the Center for Disease Control and Prevention (CDC), in 2007, pain-reliever overdose killed more people in the USA than cocaine and heroin combined [1]. Since 1999, deaths among women from prescription painkiller overdose have increased nearly $400 \%$ [2]. Over $40 \%$ of these deaths are attributed to one class of pain-relievers, the opioids [1,2]. In 2011, opioid overdose killed more Americans than traffic fatalities. Data published on the National Institute of Drug Abuse (NIDA) website [3] show a steady increase in the number of opioid prescriptions over the past two decades. Other data compiled and analyzed independently [4] support the CDC and NIDA observations, and further point to some disturbing trends. Although the number of opioid prescriptions has gone up, the number of Americans filling opioid prescriptions declined and the days of medication per prescriptions rose by $8.4 \%$. Most of the longterm opiate users are elderly; yet, young adults (22-44 yrs.) filled more prescriptions, for longer time per prescription. About $20 \%$ of these individuals use opioids for non-medical reasons. Opioid abusers and misusers include elderly, as well as college students [4]. Opioid abuse is affecting urban and rural populations [5]. American Veterans are victims of this epidemic [6] as are high school students [3]. In 2010, one out of every 12 high school seniors in USA reported abusing/misusing opioids [3]. Finally, opioid use has been shown to act as a gateway to heroin addiction [4]. Thus, opioid addiction due to their misuse or abuse is now considered a public health crisis in the USA [7] as well as other nations [8-10]. However, this problem is not limited only to opioid addiction due to abuse and misuse. New evidence also indicates iatrogenic opioid dependence and/or addiction [11], although at least one report argues to the contrary [12]. During 1999-2009, there was a parallel increase in opioid sales, treatment facilities admissions, and opioid overdose deaths in the US [1,2]. More Americans are affected by chronic pain than cancer, diabetes and all vascular disorders combined [13]. The chronic pain diagnoses, number of opioid prescriptions and admission numbers for prescription opioid abuse treatment also show a parallel growth in numbers [4] leading some experts to argue that chronic pain and prescription opioid abuse are co-existing disorders $[14,15]$.

It is clear from the foregoing analysis that opioid abuse/addiction is a rapidly growing public health issue affecting different populations globally. A number of important preventive steps such as prescription drug monitoring and compliance guidelines [16], policy and legal interventions [17], and addiction/dependence management through medication [8] have been in place, with mixed results [18-20]. Clearly, opioid-associated death is a complex problem and solving it may require a combination of multiple approaches. One tactic, which remains rather underutilized, is pharmacogenomics (PGx). During the past few years, considerable evidence has accumulated to substantiate the view that PGx has the potential to positively affect this issue in three different ways:

\section{Application}

Significant progress has already been made in understanding how genetic variations influence metabolism of codeine, the opiate agonist, which is also a constituent of many top-selling medications [21-25]. Specifically, CYP2D6 gene variants that result in drastically different pharmacokinetics of codeine metabolism and hence patient health outcomes have been reported [21-24]. One article also reports using codeine PGx to resolve a suspected opioid overdose case [25]. Wider application of codeine PGx has also been shown to reduce accidental overdosing, unintentional health complications and associated costs $[26,27]$. It is time for the regulatory agencies to make CYP2D6 genotype testing mandatory before prescribing codeine-containing medications.

\section{Education}

Lack of awareness and/or training of health care professionals, specifically primary care physicians [28-30], nurse practitioners [31] and pharmacists [32] is reported to be a major factor hindering the broader application of the approach referred above. using available continuing education programs and developing targeted programs specifically addressing when, where and how the PGx information should be sought and used would further expand the scope of application and improve healthcare outcomes as well as reduce costs.

\section{Research}

Addiction is a complex, multi-genic trait [33-35]. Most of the current applicable studies and results on PGx of pain relievers are focused on single candidate gene examples [36-39]. However, with advances in genome wide association studies [40], reduction of technology costs in whole genome sequencing/analyses, and larger numbers of trained health care professionals working in this area, new research will lead to a better understanding and characterization of genomic determinants underlying addiction behavior. This in turn will offer novel ways to manage, even cure addiction behavior. Targeted funding support from governmental and non-governmental sources will play a crucial role in furthering knowledge, identifying new target gene candidates and discovering new treatment modalities.

In summary, addiction to pain relievers is a major public health issue across the world. Significant research in opiate PGx has already provided tools and technologies that positively influence health care outcomes and reduce treatment costs via improved dosing decisions. Regulatory agencies are urged to make CYP2D6 genotype testing mandatory before prescribing codeine-containing medications. Broader application of these tools and technologies is possible through continuing education and training of practicing health care professionals. Use of advanced tools and technologies of PGx

*Corresponding author: Pramod B Mahajan, Department of Pharmaceutical Biomedical and Administrative Sciences, College of Pharmacy and Health Sciences, Drake University, 2507 University Avenue, Des Moines, IA 50311, USA, Tel: 515-2713022; Fax: 515-271-1867; E-mail: Pramod.Mahajan@Drake.edu

Received December 24, 2014; Accepted December 26, 2014; Published December 30, 2014

Citation: Mahajan PB (2014) Will Pharmacogenomics Take the Pain Out of Pain Medication?. J Pharmacogenomics Pharmacoproteomics 6: e142. doi:10.4172/2153-0645.1000e142

Copyright: (c) 2014 Mahajan PB. This is an open-access article distributed under the terms of the Creative Commons Attribution License, which permits unrestricted use, distribution, and reproduction in any medium, provided the original author and source are credited. 
Citation: Mahajan PB (2014) Will Pharmacogenomics Take the Pain Out of Pain Medication?. J Pharmacogenomics Pharmacoproteomics 6: e142. doi:10.4172/21530645.1000e142

Page 2 of 2

research will further improve identification and application of genetic determinants underlying addiction to various pain relievers. Targeted funding support from governmental and non-governmental sources for research projects in this area will further strengthen our abilities to take pain out of pain reliever medication.

\section{References}

1. http://www.cdc.gov/vitalsigns/pdf/2011-11-vitalsigns.pdf

2. http://www.cdc.gov/vitalsigns/pdf/2013-07-vitalsigns.pdf

3. http://www.drugabuse.gov/publications/research-reports/prescription-drugs/

4. http://lab.express-scripts.com/publications/a-nation-in-pain

5. Keyes KM, Cerdá M, Brady JE, Havens JR, Galea S (2014) Understanding the rural-urban differences in nonmedical prescription opioid use and abuse in the United States. Am J Public Health 104: 52-59.

6. Dabbs C, Watkins EY, Fink DS, Eick-Cost A, Millikan AM (2014) Opiate-related dependence/abuse and PTSD exposure among the active-component U.S. military, 2001 to 2008. Military Medicine 179: 885-890.

7. Katzman JG, Comerci GD, Landen M, Loring L, Jenkusky SM, et al. (2014) Rules and values: a coordinated regulatory and educational approach to the public health crises of chronic pain and addiction. Am J Public Health 104 1356-1362.

8. Ling W, Mooney L, Hillhouse M (2011) Prescription opioid abuse, pain and addiction: clinical issues and implications. Drug Alcohol Rev 56: 92-93.

9. Jafari S, Joe R (2014) Prescription medication abuse. BC Med J 56:92-93

10. Zamparutti G, Schifano F, Corkery JM, Oyefeso A, Ghodse AH (2011) Deaths of opiate/opioid misusers involving dihydrocodeine, UK, 1997-2007. Br J Clin Pharmacol 72: 330-337.

11. Beauchamp GA, Winstanley EL, Ryan SA, Lyons MS (2014) Moving beyond misuse and diversion: the urgent need to consider the role of iatrogenic addiction in the current opioid epidemic. Am J Public Health 104: 2023-2029.

12. Minozzi S, Amato L, Davoli M (2013) Development of dependence following treatment with opioid analgesics for pain relief: a systematic review. Addiction 108: 688-698.

13. Institute of Medicine. Relieving pain in America. A Blueprint for Transforming Prevention, Care, Education and Research. Washington, DC. The National Academic Press. 2011

14. Pohl M, Smith $L$ (2012) chronic pain and addiction: challenging co-occurring disorders. J Psychoactive Drugs 44: 119-124.

15. Pade PA, Cardon KE, Hoffman RM, Geppert CM (2012) Prescription opioid abuse, chronic pain, and primary care: a Co-occurring Disorders Clinic in the chronic disease model. J Subst Abuse Treat 43: 446-450.

16. Cobaugh DJ, Gainor C, Gaston CL, Kwong TC, Magnani B, et al. (2014) The opioid abuse and misuse epidemic: implications for pharmacists in hospitals and health systems. Am J Health Syst Pharm 71: 1539-1554.

17. Fischer B, lalomiteanu A, Kurdyak P, Mann RE, Rehm J (2013) Reductions in non-medical prescription opioid use among adults in Ontario, Canada: are recent policy interventions working? Subst Abuse Treat Prev Policy. 8: 1-7.

18. McDonald J (2013) Opioid prescribing: guidelines, laws, rules, regulations, policies, best practices. R I Med J (2013) 96: 38-41.

19. Lexchin J, Kohler JC (2011) The danger of imperfect regulation: OxyContin use in the United States and Canada. Int J Risk Saf Med 23: 233-240.

20. Jones CM, Lurie P, Woodcock J (2014) Addressing prescription opioid overdose: data support a comprehensive policy approach. JAMA 312: 17331734.

21. Ciszkowski C, Madadi P, Phillips MS, Lauwers AE, Koren G (2009) Codeine ultrarapid-metabolism genotype, and postoperative death. N Engl J Med 361 : 827-828.

22. Kelly LE, Rieder M, Anker JVD, Malkin B, Ross C, et al. (2012) More codeine fatalities after tonsillectomy in North American children. Pediatrics 129: e13431347.
23. Madadi P, Amstutz U, Rieder M, Ito S, Fung V et al. (2013) Clinical practice guideline: CYP2D6 genotyping for safe and efficacious codeine therapy. $J$ Popul Ther Clin Pharmacol 20: e369-396.

24. Crews KR, Gaedigk A, Dunnenberger HM, Leeder JS, Klein TE et al. (2014) Clinical Pharmacogenetics Implementation Consortium guidelines for cytochrome P450 2D6 genotype and codeine therapy: 2014 update. Clin Pharmacol Ther 95:376-382.

25. Shaw KD, Amstutz U, Jimenez-Mendez R, Ross CJ, Carleton BC (2012) Suspected opioid overdose case resolved by CYP2D6 genotyping. Ther Drug Monit 34: 121-123.

26. Kessler ER, Shah M, Gruschkus SK, Raju A (2013) Cost and quality implications of opioid-based postsurgical pain control using administrative claims data from a large health system: opioid-related adverse events and their impact on clinical and economic outcomes. Pharmacotherapy 33: 383-391.

27. Xu Y, Johnson A (2013) Opioid therapy pharmacogenomics for noncancer pain: efficacy, adverse events, and costs. Pain Res Treat 2013: 943014.

28. Johansen Taber KA, Dickinson BD (2014) Pharmacogenomic knowledge gaps and educational resource needs among physicians in selected specialties. Pharmgenomics Pers Med 7: 145-162.

29. Bernhardt BA, Zayac C, Gordon ES, Wawak L, Pyeritz RE, et al. (2012) Incorporating direct-to-consumer genomic information into patient care: attitudes and experiences of primary care physicians. Per Med 9: 683-692.

30. Haga SB, Burke W, Ginsburg GS, Mills R, Agans R (2012) Primary care physicians' knowledge of and experience with pharmacogenetic testing. Clin Genet 82: 388-394.

31. DeFeo K, Sykora K, Eley S, Vincent D (2014) How does pharmacogenetic testing alter the treatment course and patient response for chronic-pain patients in comparison with the current "trial-and-error" standard of care? J Am Assoc Nurse Pract 26: 530-536.

32. Tuteja S, Haynes K, Zayac C, Sprague JE, Bernhardt B1, et al. (2013) Community pharmacists' attitudes towards clinical utility and ethical implications of pharmacogenetic testing. Per Med 10.

33. Trescot AM, Faynboym S (2014) A review of the role of genetic testing in pain medicine. Pain Physician 17: 425-445.

34. Young EE, Lariviere WR, Belfer I (2012) Genetic basis of pain variability: recent advances. J Med Genet 49: 1-9.

35. Al-Eitan LN, Jaradat SA, Hulse GK, Tay GK (2012) Custom genotyping fo substance addiction susceptibility genes in Jordanians of Arab descent. BMC Res Notes 5: 497.

36. Manini AF, Jacobs MM, Vlahov D, Hurd YL (2013) Opioid receptor polymorphism A118G associated with clinical severity in a drug overdose population. J Med Toxicol 9: 148-154

37. Clarke TK, Crist RC, Kampman KM, Dackis CA, Pettinati HM, et al. (2013) Low frequency genetic variants in the $11 / 4$-opioid receptor (OPRM1) affect risk for addiction to heroin and cocaine. Neurosci Lett 542: 71-75.

38. Beer B, Erb R, Pavlic M, Ulmer H, Giacomuzzi S, et al. (2013) Association of polymorphisms in pharmacogenetic candidate genes (OPRD1, GAL, ABCB1, OPRM1) with opioid dependence in European population: a case-control study. PLoS One 8: e75359.

39. Bunten H, Liang WJ, Pounder DJ, Seneviratne C, Osselton D (2011) Interindividual variability in the prevalence of OPRM1 and CYP2B6 gene variations may identify drug-susceptible populations. J Anal Toxicol 35: 431437

40. Hall FS, Drgonova J, Jain S, Uhl GR (2013) Implications of genome wide association studies for addiction: are our a priori assumptions all wrong? Pharmacol Ther 140: 267-279. 